\title{
Pure Lymphocytic Infundibuloneurohypophysitis Caused by the Rupture of Rathke's Cleft Cyst: Report of 2 Cases and Review of the Literature
}

\author{
Rathke Yarnğ Kisti Rüptürü Nedeniyle Saf Lenfositik \\ Infundibulonörohipofizit: İki Olgu Sunumu ve Literatür Derlemesi
}

Yasuhiko HAYASHI, Masahiro OISHI, Daisuke KITA, Takuya WATANABE, Osamu TACHIBANA, Jun-ichio HAMADA

Kanazawa Medical University, Department of Neurosurgery, Kanazawa, Japan

Corresponding Author: Yasuhiko HAYASHI / E-mail: yahayashi@med.kanazawa-u.ac.jp

\begin{abstract}
The major symptoms that are caused by Rathke's cleft cysts (RCCs) are visual disturbances, headaches, and endocrine insufficiencies. Among these symptoms, the endocrine insufficiencies are thought to result from the spreading of inflammation that is induced by the cyst contents onto the pituitary gland or the compression of the gland and the pituitary stalk by RCCs. Here, we present 2 rare cases with lymphocytic infundibulohypophysitis with the sudden onset of headaches and subsequent diabetes insipidus (DI). Magnetic resonance imaging revealed remarkable swelling of the pituitary gland with a small mass that was located between the anterior and the posterior lobe of the pituitary gland. Transsphenoidal surgery was performed to remove the mass, and pathological examinations of the cyst wall demonstrated that the epithelial tissue of the RCC and the posterior lobe were affected by massive lymphocytic infiltration. The clinical courses and pathological results of these patients strongly suggested that the rupture of the RCC onto the posterior lobe caused the lymphocytic hypophysitis. Postoperatively, the DI could be controlled with a smaller amount of anti-diuretic hormone replacement compared to that required preoperatively.
\end{abstract}

KEYWORDS: Hypophysitis, Rathke's cleft cyst, Lymphocyte, Diabetes insipidus

öz

Rathke yarığı kistlerinin (RCC'ler) neden olduğu ana belirtiler görme bozuklukları, baş ağrıları ve endokrin yetmezliklerdir. Bu belirtiler arasında endokrin yetmezliklerin, kist içeriğinin oluşturduğu enflamasyonun hipofize yayılması veya hipofizin ve hipofiz sapının RCC'ler ile kompresyonu sonucunda oluştuğu düşünülmektedir. Makalede, aniden baş ağrısı ve sonrasında diabetes insipidus (DI) gelişen 2 nadir lenfositik infundibulohipofizit olgusu sunuldu. Manyetik rezonans görüntüleme hipofizin anterior ve posterior lobu arasında küçük bir kitleyle birlikte hipofizde belirgin şişme göstermiştir. Kitleyi çıkarmak için transsfenoidal cerrahi yapılmış ve kist duvarının patoloji incelemeleri epitelyal RCC dokusu ve posterior lobda masif lenfositik infiltrasyon göstermiştir. Bu hastalarda klinik seyir ve patoloji sonuçları, lenfositik hipofizitin nedeninin RCC'nin posterior loba rüptürü olduğunu kuvvetle düşündürmüştür. Postoperatif olarak DI preoperatif olarak gerekenden daha az miktarda antidiüretik hormon replasmanıyla kontrol altına alınabilmiştir.

ANAHTAR SÖZCÜKLER: Hipofizit, Rathke yarığı kisti, Lenfosit, Diabetes insipidus

Abbreviations: DDAVP: 1-deamino-8-D-arginine vasopressin, DI: diabetes insipidus, HE: hematoxylin and eosin, MRI: magnetic resonance imaging, RCC: Rathke's cleft cyst, WI: weighted images

\section{INTRODUCTION}

Rathke's cleft cyst (RCC) is a non-neoplastic sellar and suprasellar lesion that develops from the remnants of the Rathke's pouch at the pars intermedia. Although it is infrequent, RCCs become symptomatic when they are large enough to compress surrounding structures such as the optic chiasm, the pituitary gland, the hypothalamus, or the diaphragma sellae $(5,15)$. In addition, many authors have reported that RCCs cause endocrinologic abnormalities because of the inflammatory spreading of the RCC contents that contain mucin, and this can involve the surrounding pituitary gland $(9,17,21)$.

Inflammatory lesions of the pituitary gland are rare and such hypophysitises are classified as lymphocytic, granulomatous, xanthomatous, or secondary (1). The underlying mechanisms that cause such inflammatory responses include autoimmune mechanisms, pregnancy, and some unknown etiologies (3). RCCs have been reported to cause various types of 
hypophysitises, and the sudden onset of the symptoms that are induced by such inflammatory responses suggests that the RCC contents have ruptured and spread onto the pituitary gland $(3,11)$.

\section{CASE REPORT}

\section{Case 1}

A 67-year-old woman presented with a sudden onset of headache and excessive thirst without any inciting causes. Magnetic resonance imaging (MRI) revealed enlargement of the pituitary gland and a small mass at the pars intermedia, in which hypointensity on T1-weighted images (WIs) and hyperintensity on T2-WIs suggested RCC. Hyperintensity of the posterior lobe on T1-WIs was not found (Figure 1A-D). Endocrine studies showed that all of the hormonal secretions from the anterior lobe were within the normal range for normal menopausal woman; free triiodothyronin (T3: 2.99 $\mathrm{pg} / \mathrm{ml}$, normal range 2.2-4.3), free thyroxin (T4: $1.19 \mathrm{ng} / \mathrm{ml}$, range: $0.8-1.8)$, thyroid stimulating hormone (TSH: $1.26 \mathrm{mU} /$ $\mathrm{ml}$, range: 0.27-4.65), luteinizing hormone (LH: $19.6 \mathrm{mUl} /$ $\mathrm{ml}$, range 5.7-64.3), follicle-stimulating hormone ( $\mathrm{FSH}: 47.6$ $\mathrm{mUl} / \mathrm{ml}$, range $<0.5)$, prolactin $(18.2 \mathrm{ng} / \mathrm{ml}$, range: $<25.6), \mathrm{GH}$
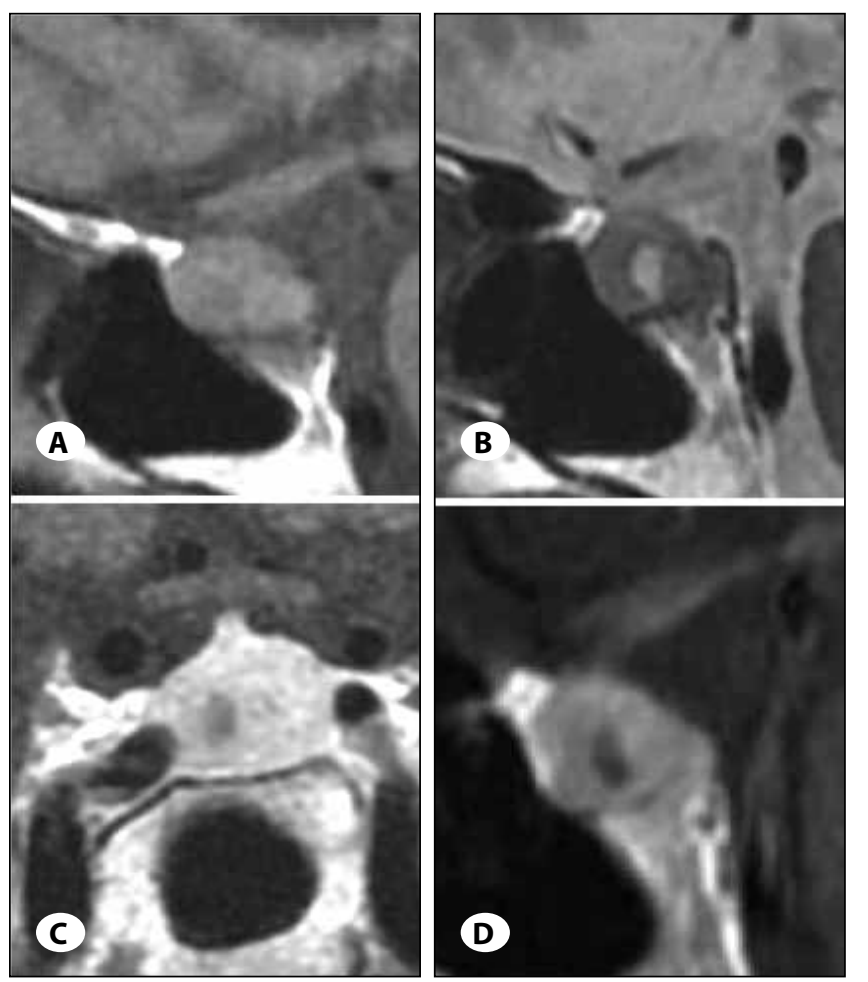

Figure 1: Sagittal section of magnetic resonance image (MRI) that was obtained at admission showing a small mass at the pars intermedia, A) hypointensity on a T1-weighted image (WI), and B) hyperintensity on a T2-WI. Hyperintensity of the posterior lobe in the pituitary gland was not found on the T1-WI. C) Coronal and D) sagittal section of an MRI revealing uniform enhancement of the entire enlarged pituitary gland and a hypointense area on a T1-WI without enhancement, suggesting a Rathke's cleft cyst (RCC).
(0.49 ng/ml, range <2.1), IGF-1 (142 g/ml, range: 109-307), cortisol ( $8.0 \mathrm{mg} / \mathrm{m}$, range: $6.2-19.7)$, ACTH (45.3 pg/ml, range: <46). The observations of low levels of urine osmolarity (158 mOsm/l, range: 90-1400), that were due to a lack of increase by hypertonic saline loading, urine specific gravity (1.0011.003, range: 1.005-1.025), and urine volume per day over $6,000 \mathrm{ml}$ resulted in the diagnosis of the central type of diabetes insipidus (DI).

The aspiration of the RCC contents with endoscopic endonasal transsphenoidal surgery was planned to prevent further spreading of the inflammation. Minimum dissection of the anterior lobe of the pituitary gland led to the outflow of white turbid fluid. The results of a pathological examination showed columnar ciliated epithelia, which was consistent with a diagnosis of RCC. The RCC wall was disrupted with lymphocytes infiltration onto the adjacent posterior lobe (Figure 2A-D). Silver impregnation showed broken reticulin fibers at the posterior lobe despite preservation at the anterior lobe.

The postoperative clinical course was uneventful with steroid administration for a week, and the RCC was completely diminished on MRI (Figure 3). Her DI gradually improved
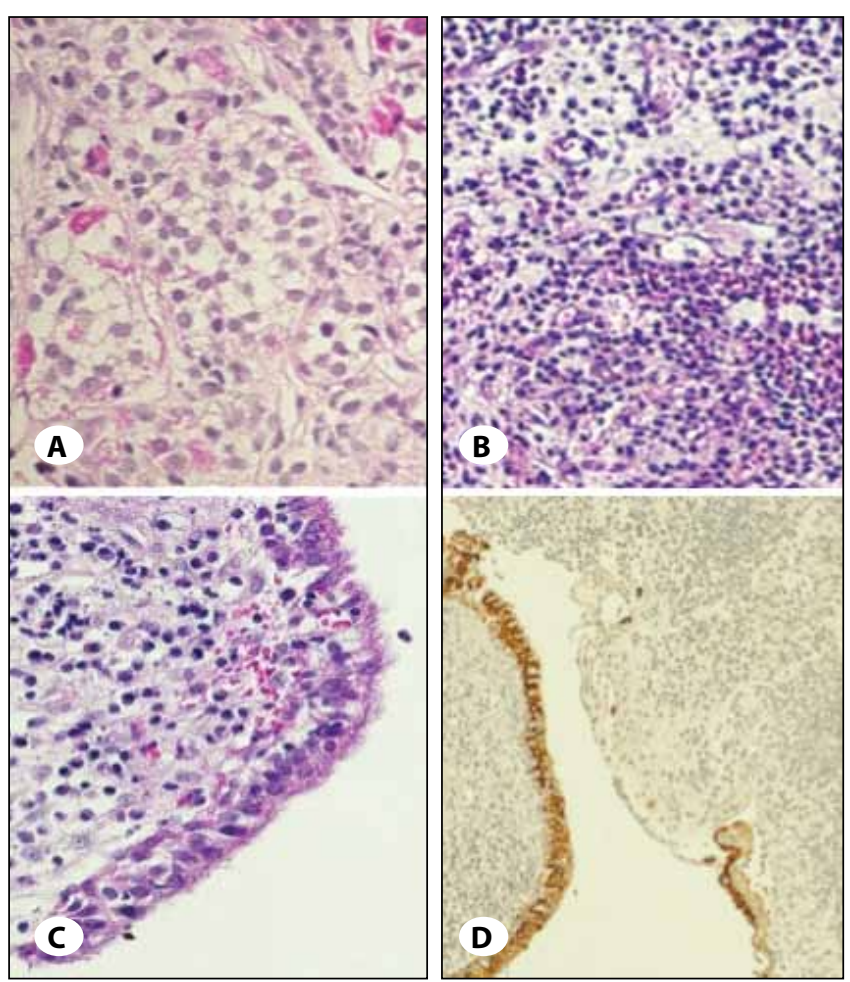

Figure 2: Photomicrographs showing $\mathbf{A}$ ) preservation of normal acinar structures at the anterior lobe and B) massive lymphocytes infiltrating mainly into the posterior lobe. C) Columnar cells lined with cilia on the surface of the cyst indicating RCC (hematoxylin and eosin [HE] stain, original magnification x100). D) Immunohistochemical staining with Cam 5.2 clearly revealed disruption of RCC wall and massive infiltration of lymphocytes onto the adjacent posterior lobe (original magnification $\times 40$ ). 
and required less amount of administration of 1-deamino-8D-arginine vasopressin (DDAVP) compared to that required preoperatively.

\section{Case 2}

A 55-year-old man suffered a sudden onset of headache and subsequent strong thirst without any inciting causes. MRI revealed the pituitary gland was swollen and a small cystic mass at the pars intermedia, and isointensity on T1-WIs and

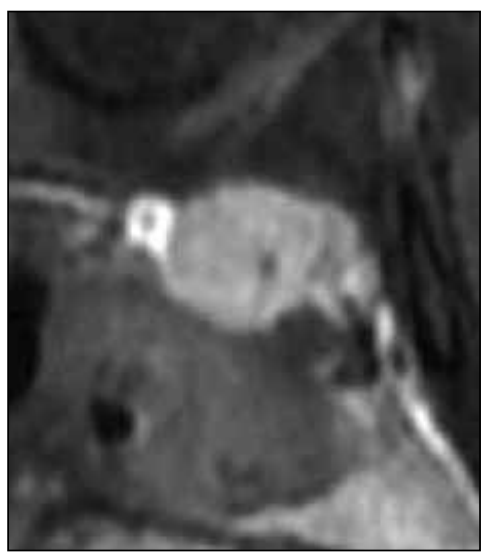

Figure 3: Postoperative sagittal section of an MRIT1-WI with contrast enhancement displaying the removal of the RCC.
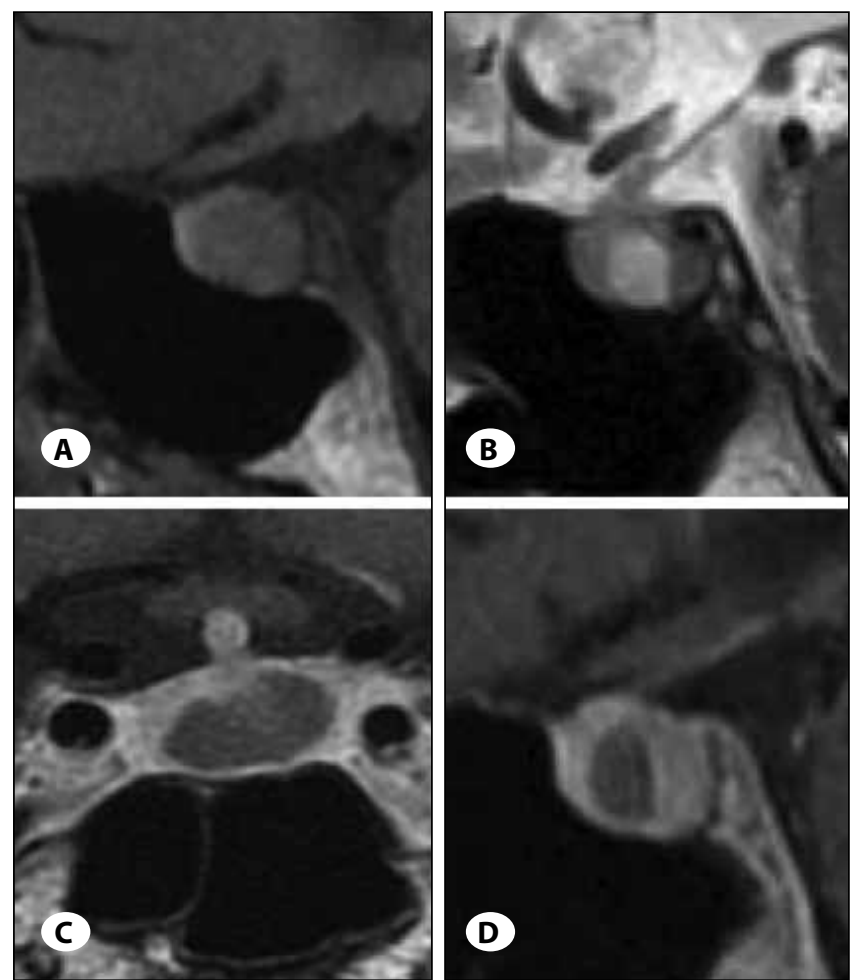

Figure 4: Sagittal section of an MRI obtained at admission showing a small mass at the pars intermedia, $\mathbf{A}$ ) hypointensity on a T1-WI, and B) hyperintensity on a T2-WI. Hyperintensity of the posterior lobe in the pituitary gland could not be detected on the T1-WI. C) Coronal and D) sagittal section of an MRI revealing uniform enhancement of the entire enlarged pituitary gland and an area of hypointensity on a T1-WI without enhancement, suggesting a RCC. hypointensity in hyperintensity on T2-Wls suggested RCC. No hyperintensity of the posterior lobe on T1-WIs could be seen (Figure 4A-D). Endocrinologic examinations demonstrated that all the hormones derived from the anterior lobe were within the normal range; free T3 $(2.82 \mathrm{pg} / \mathrm{ml})$, free T4 (1.28 $\mathrm{ng} / \mathrm{ml}), \mathrm{TSH}(2.33 \mathrm{mU} / \mathrm{ml}), \mathrm{LH}(7.30 \mathrm{mUl} / \mathrm{ml}), \mathrm{FSH}(8.1 \mathrm{mUl} /$ $\mathrm{ml})$, prolactin $(7.56 \mathrm{ng} / \mathrm{ml}), \mathrm{GH}(0.77 \mathrm{ng} / \mathrm{ml}), \mathrm{GF}-1(144 \mathrm{~g} /$ $\mathrm{ml}$ ), cortisol, (17.8 mg/ml), and ACTH (25.1 pg/ml). Low levels of urine osmolarity (184 mOsm/l) were observed, and hypertonic saline loading did not induce an increase. Urine specific gravity (1.001-1.003) and urine volume per day over $5000 \mathrm{ml}$ were compatible with the central type of DI.

The evacuation of the RCC contents with endoscopic endonasal transsphenoidal surgery was conducted so that the subsequent inflammatory response would not spread. The inferior portion of the cyst and the anterior lobe of the pituitary gland were incised to allow flow of the turbid yellowish fluid flow out of the cyst. A pathological examination revealed columnar ciliated epithelia, which was diagnosed as RCC. The wall of RCC was disrupted with massive lymphocytes infiltration onto the close posterior lobe (Figure 5A-D).

He was discharged after being treated with appropriate steroid administration for a week, and MRI showed the complete
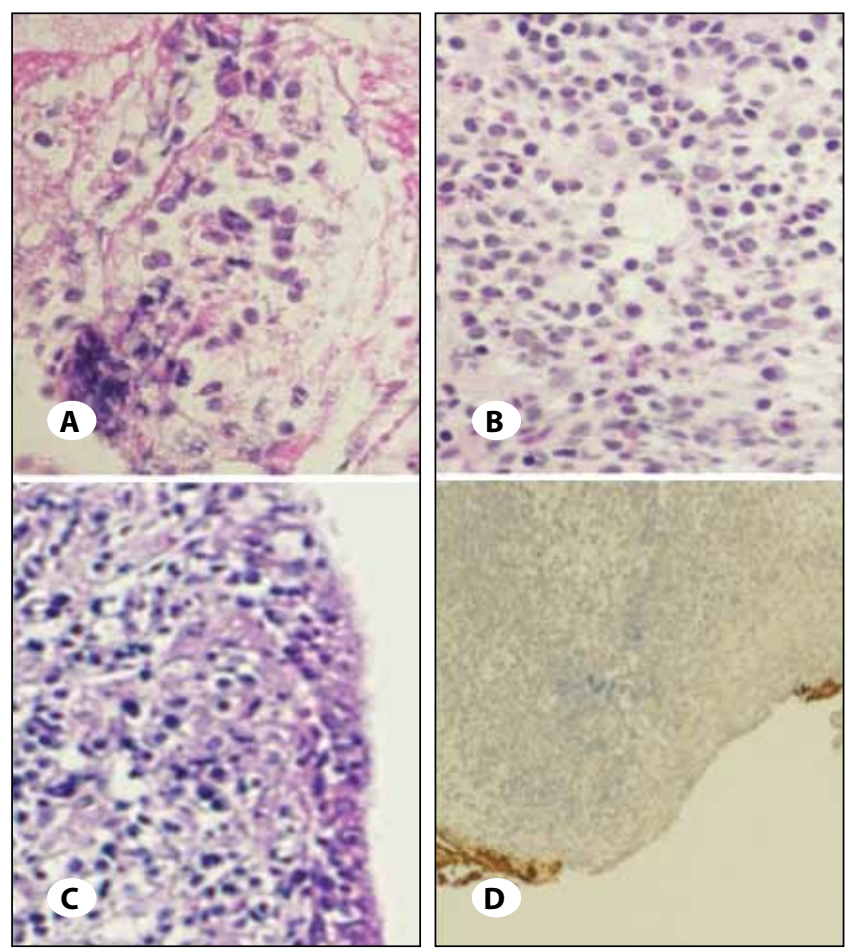

Figure 5: Photomicrographs showing $\mathbf{A}$ ) the preservation of normal acinar structures at the anterior lobe and B) massive lymphocytes infiltrating mainly into the posterior lobe. C) Columnar cells lined with cilia on the surface of the cyst indicating RCC (HE stain, original magnification $\times 100)$. D) Immunohistochemical staining with Cam 5.2 clearly revealed disruption of RCC wall and massive infiltration of lymphocytes onto the adjacent posterior lobe (original magnification $\times 40$ ). 
Table I: Secondary Hypophysitis with Diabetes Insipidus due to Rupture of RCC

\begin{tabular}{|l|l|c|l|l|l} 
& Cases & Age/Sex & Type of hypophysitis & Clinical Symptoms & $\begin{array}{l}\text { Depressed ant. lobe } \\
\text { hormone }\end{array}$ \\
\hline 1 & Nishikawa et al. (17) & $62 / F$ & lymphocytic & hemianopsia, polyuria & ACTH, TSH \\
\hline 2 & Sonnet et al. (21) & $29 / F$ & lymphocytic & headache, polyuria & ACTH, TSH \\
\hline 3 & Yuyama et al. (22) & $30 / F$ & lymphocytic & hemianopsia, polyuria & ACTH \\
\hline 4 & Hama et al. (9) & $48 / F$ & xanthogranulomatous & hemianopsia, polyuria & GH, TSH, LH \\
\hline 5 & Daikokuya et al. (3) & $61 / F$ & lymphocytic & hemianopsia, polyuria & GH, TSH \\
\hline 7 & Janeczko et al. (14) & $53 / F$ & lymphocytic & headache, polyuria & ACTH, FSH, LH, GH \\
\hline 8 & Our case 1 & $69 / F$ & lymphocytic & headache, polyuria & - \\
\end{tabular}

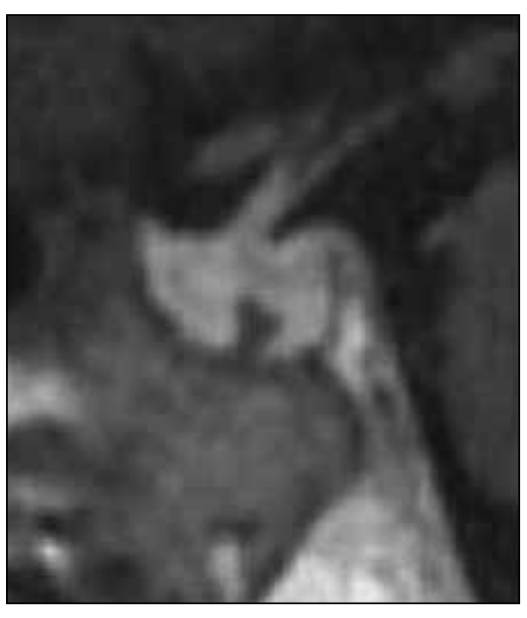

Figure 6:

Postoperative sagittal section of an MRI T1-WI with contrast enhancement displaying the removal of the RCC.

disappearance of RCC (Figure 6). However, a reduced amount of DDAVP was needed to control his DI postoperatively.

\section{DISCUSSION}

Lymphocytic hypophysitis is generally considered an autoimmune disease that is more often observed in women at the end of or immediately after their pregnancy $(19,21)$. Pituitary gland biopsies can reveal perivascular mast cells and lymphoplasmacytic infiltration surrounding atrophic acini $(3,11,17)$. The involvement of the posterior lobe and pituitary stalk may result in DI as a clinical sign, which is demonstrated with the disappearance of hyperintensity signals on T1-WIs (20).

The inflammatory origin of the secondary hypophysitis is triggered by systemic disease, infectious agents, or adjacent lesions. Histological features can show a mixture of all 3 of the previously described types; lymphocytic, granulomatous and xanthomatous (1). In our cases, systemic diseases, such as sarcoidosis (2), Langerhans cell histiocytosis (4), lupus erythematosus (10), and Wegener's granulomatosis (7) were ruled out in addition to bacterial and fungal infections. Several lesions that are associated with hypophysitis include pituitary adenoma (12), germinoma (6), craniopharyngioma (18), inflammatory pseudotumors (16), and RCC $(10,11,17,21,22)$.
To the best of our knowledge, six cases have been reported as secondary hypophysitis with DI due to the rupture of RCCs. Among them, five cases have been classified as lymphocytic and the other one as xanthomatous hypophysitises. All of them were reported to be suffering from endocrine dysfunction or lymphocyte infiltration in both the anterior lobe and the posterior lobe (Table I). In both of our cases, the endocrinologic functions of the anterior lobe were preserved both after the rupture of RCCs and the operations. In addition, the pathological examinations demonstrated that the massive lymphocyte infiltration did not involve the anterior lobe.

The detailed developing mechanisms of the hypophysitis that is associated with RCC remain unknown, but it is believed that the spread of chemical materials induces inflammation of the adjacent adenohypophysis or neurohypophysis. In cases with hypophysitis, the cyst wall undergoes hyperplastic and metaplastic changes from being single-layered to becoming a stratified epithelium during the progression of inflammation (9). Some authors have insisted that the mucus in the contents of the RCC may be a strong stimulator of tissue injury with not only lymphocytic but also granulomatous reactions in the epithelial cyst wall $(9,21)$. In our cases, the surgical specimens clearly demonstrated massive lymphocyte infiltration only into the posterior lobe with severely damaged pituitary architecture, indicating inflammatory destruction by autoimmune reactions (17). In addition, it was suggested that the lymphocyte infiltration that mainly occurred along the widely disrupted RCC wall resulted from the rupture of RCC with the sudden onset of headaches.

The diagnosis of a ruptured RCC should be based on radiological findings that display shrinkage of the cyst $(17,20)$. However, in our case, we assumed RCC rupture and leakage of the cyst contents into the posterior lobe, based on the clinical findings of sudden onset of headache and endocrine dysfunction of the posterior lobe alone, and the pathological findings of the posterior lobe affected with massive lymphocyte infiltration. The cyst fluid leakage might activate an autoimmunogenic process with lymphocytes $(3,14,22)$. In our cases, histological examinations displayed no granulomatous or fibrous changes that indicated chronic inflammatory changes in the surrounding structure. 
It is thought that the determining factors that limit the range of RCC contents within the posterior lobe are the size of the cyst and fistula, in addition to the direction of the rupture. In both of our cases, the small size of the cyst and the speculated direction of rupture to the posterior lobe were attributed to the occurrence of pure neurohypophysitis.

The optimal management of hypophysis problems can be achieved through surgical biopsy and histological diagnosis. The removal of abnormally lymphocyte-infiltrated inflammatory tissue with severely disrupted pituitary architecture is helpful for preserving and recovering the less affected pituitary functions partially or even completely $(8,13)$. The surgical removal of the RCC contents was considered in order to eliminate the source of the inflammation or the immunogenic response into the pituitary gland. We need to stress that an accurate diagnosis and prompt procedure should be performed within the acute or subacute phase of hypophysitis cases, when the irreversible changes of the pituitary gland remain minimal $(8,20)$. If hypophysitis due to RCC rupture is found at the chronic stage, it is not expected that surgery will be beneficial. In both of our cases, surgical removal at the early phase resulted in partial relief of the DI in terms of reducing the amount of DDAVP that was necessary to be administered.

\section{REFERENCES}

1. Bellastella A, Bizzarro A, Coronella C, Bellastella G, Sinisi AA, De Bellis A: Lymphocytic hypophysitis: A rare or underestimated disease? Eur J Endocrinol 149: 363-376, 2003

2. Bullmann $C$, Faust $M$, Hoffmann A, Heppner $C$, Jockenhovel F, Muller-Wieland D, Krone W: Five cases with central diabetes insipidus and hypogonadism as first presentation of neurosarcoidosis. Eur J Endocrinol 142: 365-372, 2003

3. Daikokuya H, Inoue Y, Nemoto Y, Tashiro T, Sahkudo M, Ohata K: Rathke's cleft cyst associated with hypophysitis: MRI. Neuroradiology 42: 532-534, 2000

4. Donadieu J, Rolon MA, Thomas C, BrugieresL, Plantaz D, Francois EJ, Frappaz D, David M, Brauner R, Genereau T, Debray D, Cabrol S, Barthez MA, Hoang-Xuan K, Polak M: Endocrine involvement in pediatric-onset Langerhans' cell histiocytosis: A population based study. J Pediatr 144: 344350, 2004

5. El-Mahdy W, Powall M: Transphenoidal management of 28 symptomatic Rathke's cleft cyst, with special references to visual and hormonal recovery. Neurosurgery 42: 7-16, 1998

6. Fehn M, Bettendorf M, Ludecke DK, Sommer C, Saeger W: Lymphocytic hypophysitis masking a suprasellar germinoma in a 12-year-old girl: A case report. Pituitary 1: 303-307, 1999

7. Goyal M, Kucharczyk W, Keystone E: Granulomatous hypophysitis due to Wegener's granulomatosis. Am J Neuroradiol 21: 1466-1469, 2000

8. Gutenberg A, Hans V, Puchner MJ, Kreutzer J, Bruck W, Caturegli P, Buchfelder M: Primary hypophysitis: Clinicalpathological correlation. Eur J Endocrinol 155: 101-107, 2006
9. Hama S, Arita K, Nishisaka T, Fukuhara T, Tominaga A, Sugiyama K, Yoshikawa M, Eguchi K, Sumida M, Heike Y, Kurisu $\mathrm{K}$ : Changes in the epithelium of Rathke cleft cyst associated with inflammation. J Neurosurg 96: 209-216, 2002

10. Hashimoto K, Asaba K, Tamura K, Takao T, Nakamura T: A case of lymphocytic infundibuloneurohypophysitis associated with systemic lupus erythematosus. Endocr J 49:605-610, 2002

11. Hashimoto K, Takao T, Makino S: Lymphocytic adenohypophysitis and lymphocytic infundibuloneurohypophysitis. Endcr J 44: 1-10, 1997

12. Heshmati HM, Kujas M, Casanova S, Wollan PC, Racadot J, Van Effenterre R, Derome PJ, Turpin G: Prevalence of lymphocytic infiltrate in 1400 pituitary adenomas. Endocr J 45: 357-361, 1998

13. Honegger J, Furlbusch R, Bornemann A, Hensen J, Buchfelder M, Muller M, Nomikos P: Lymphocytic and granulomatous hypophysitis: Experience with nine cases. Neurosurgery 40 : 713-722, 1997

14. Janeczko C, McHugh J, Rawluk D, Farrell M, Brennan $P$, Delanty N: Hypophysitis secondary to ruptured Rathke's cyst mimicking neurosarcoidosis. J Clin Neurosci 16:599-600, 2009

15. Kim JE, Kim JH, Kim OL, Paek SH, Kim DG, Chi JG, Jung HW: Surgical treatment of symptomatic Rathke's cleft cysts: Clinical features and results with special attention to recurrence. J Neurosurg 100: 33-40, 2004

16. Kita D, Tachibana O, Nagai $Y$, Sano H, Yamashita J: Granulomatous pachymeningitis around the sella turcica (Tolosa-Hunt syndrome) involving the hypophysis. Neurol Med Chir (Tokyo) 47: 85-88, 2007

17. Nishikawa T, Takahashi JA, Shimatsu A, Hashimoto N: Hypophysitis caused by Rathke's cleft cyst. Case report. Neurol Med Chir 47: 136-139, 2007

18. Pachner MJ, Ludecke DK, Saeger W: The anterior pituitary lobe in patients with cystic craniopharyngiomas: Three cases of associated lymphocytic hypophysitis. Acta Neurochir 126: 38-43, 1994

19. Sautner D, Saeger W, Ludecke DK, Jansen V, Puchner MJ: Hypophysitis in surgical and autoptical specimens. Acta Neuropathol 90: 637-644, 1995

20. Schittenhelm J, Beschorner R, Psaras T, Capper D, Nagele T, Meyermann R, Saeger W, Honegger J, Mittelbronn M: Rathke's cleft cyst rupture as potential event of a secondary perifocal lymphocytic hypophysitis: Proposal of an unusual pathogenetic event and review of the literature. Neurosurg Rev 31:157-163, 2008

21. Sonnet E, Roudaut N, Meriot P, Bessen G, Kerlan V: Hypophysitis associated with a ruptured Rathke's cleft cyst in a woman, during pregnancy. J Endocrinol Invest 29: 353-357, 2006

22. Yuyama R, Kojima H, Mizutani T, Suzuki Y, Miki Y: Secondary pan-hypophysitis caused by rupture of Rathke's cleft cyst. No Shinkei Geka 30: 95-99, 2002 